\title{
Detection of genetically modified organisms in soy products sold in Turkish market
}

\author{
Merve MANDACI ${ }^{1}$, Özgür ÇAKIR ${ }^{1 \star}$, Neslihan TURGUT-KARA ${ }^{1}$, Sinan MERIÇ ${ }^{1}$, Şule ARI ${ }^{1,2}$
}

\begin{abstract}
PCR-based technique for GMO detection is the most reliable choice because of its high sensitivity and specificity. As a candidate of the European Union, Turkey must comply with the rules for launching into the market, traceability, and labeling of GMOs as established by EU legislation. Therefore, the objective of this study is to assess soybean products in the Turkish market to verify compliance with legislation using qualitative Polymerase Chain Reaction (PCR) assay to detect the presence of GM soybean and to quantify its amount of GM soybean in the samples tested positive using real-time PCR. DNA extracted by the modified CTAB method was properly used for PCR amplification of food materials. The amplification of a $118 \mathrm{bp}$ DNA fragment of the lectin gene from soybean by PCR was successfully achieved in all samples. The GMO screening was based on the detection of $35 \mathrm{~S}$ promoter and NOS terminator sequences. The GM positive samples were subjected to detection of Roundup Ready ${ }^{\mathrm{TM}}$ soybean (RR) using quantitative real-time PCR. It was found that $100 \%$ of the tested food samples contained less than 0.1 per cent of EPSPS gene.
\end{abstract}

Keywords: genetically modified organisms; soybean; Glycine max; real-time PCR; Roundup Ready ${ }^{\mathrm{TM}}$.

\section{Introduction}

Scientists are able to transfer genes for herbicide tolerance and insect resistance into traditional crops as a result of the achievements in molecular biology techniques (Block et al., 1987; Moellenbeck et al., 2001). Soybean (Glycine max L.) comprises the major part of the GM crop species planted since the soybean-planted areas account for nearly $50 \%$ of the total world's GM planted areas (James, 2011). The first crop approved for food production was Roundup Ready $\left(\mathrm{RR}^{\mathrm{TM}}\right)$ soybean in 1996, and it is now the most common transgenic Soybean line (Rott et al., 2004). It was developed by Monsanto and confers tolerance to Roundup herbicide. This event harbours a 35S promotor, a CTP4 leader sequence from Petunia hybrida and the 5-enol- pyruvyl shikimat-3- phosphate synthase (EPSPS) gene from Agrobacterium tumefaciens, confering the herbicide tolerance and an Agrobacterium tumefaciens nopaline synthase (nos) terminator (Monsanto Company, 2000).

Soybean is an important source of protein and vegetable oil (Friedman \& Brandon, 2001; Korth, 2008). The use of GM soybean seeds for food production has been continuously increasing in the world (James, 2011). Most of the soybeans consumed in Turkey are imported from other countries where GM soybeans are grown. Thus, detection and/or quantification of GM soybeans in processed foods is one of the most important consumer concerns regarding food safety and quality.

There are many things affecting the Polymerase Chain Reaction (PCR) amplification, such as the set up of the laboratory, PCR reactants, and sample types and primers, but the DNA extaction method is very important in GMO analysis because sample types are diverse and DNA quality is of very high concern. Recently, several methods have been developed for GMO detection and quantitation, mostly based on DNA techniques, since protein-based methods are not reliable for highly processed food analysis (Branquinho et al., 2012; Randhawa et al., 2014; Fraiture et al., 2014; Song et al., 2014). However, PCR (Mullis \& Faloona, 1987) have become essential for the control of the presence of genetically modified DNA. On the other hand, the successful DNA amplification methods depend on the efficiency of DNA extraction protocols, which is considered as a critical task in the analysis of complex or highly processed food matrices. The aim of the present study was to detect GMO from processed soy products using PCR technique and to monitor the presence of Roundup Ready ${ }^{\mathrm{TM}}$ soybean qualitatively and quantitatively.

\section{Materials and methods}

\subsection{Samples}

Soy flour, soy meat, soy cream, soy sprout-1, soy sprout-2, soy milk, soy coffee, tofu, and soy chop meat were analyzed in this study. Products were purchased randomly from markets in Istanbul, Turkey. The year of sampling was 2009. Three units of each sample were used.

\subsection{DNA extraction using CTAB method}

Genomic DNA extraction by CTAB method was performed according to Somma (2006) with some modifications. Modifications are shown in Table 1. A total amount of $100 \mathrm{mg}$ (solid samples) or $100 \mathrm{ml}$ (liquid samples) of each sample,

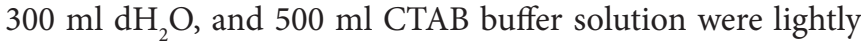
mixed. Next, $20 \mathrm{ml}$ Proteinase $\mathrm{K}(20 \mathrm{mg} / \mathrm{ml})$ were added, and 
the mixture was heated at $65^{\circ} \mathrm{C}$ for $90 \mathrm{~min}$. An aliquot of $20 \mathrm{ml}$ RNase A solution $(10 \mathrm{mg} / \mathrm{ml})$ was added, and the mixture was again heated at $65^{\circ} \mathrm{C}$ for $10 \mathrm{~min}$. The mixture was centrifuged for $10 \mathrm{~min}$ at $16000 \mathrm{xg}$. After the supernatant was transferred to a new tube which contained $500 \mathrm{ml}$ chloroform, the mixture was centrifuged for $10 \mathrm{~min}$ at $16000 \mathrm{xg}$. An aliquot of $500 \mathrm{ml}$ of upper layer was transferred to a new tube which contained equal volume of chloroform. The mixture was centrifuged for $5 \mathrm{~min}$ at $16000 \mathrm{xg}$. The upper layer was mixed with 2 volumes of $\mathrm{CTAB}$ precipitation solution and incubated at room temperature for an hour. The mixture was centrifuged for $5 \mathrm{~min}$ at $16000 \mathrm{xg}$. The precipitate was dissolved in $350 \mathrm{ml} 1.2 \mathrm{M} \mathrm{NaCl}$ solution, then $350 \mathrm{ml}$ chloroform were added and centrifuged for $10 \mathrm{~min}$ at $16000 x g$. The upper layer was mixed with 0.6 volumes of isopropanol and centrifuged for $10 \mathrm{~min}$ at $16000 \mathrm{xg}$. The precipitate was washed with $70 \%$ ethanol and dissolved in $100 \mathrm{ml}$ of water. DNA was analyzed using $1.8 \%$ agarose gel electrophoresis and was visualized with a UV transilluminator after staining with $0.5 \mathrm{~g} / \mathrm{ml}$ of ethidium bromide. Certified Reference Materials (CRM's), consisted of $0 \%$ and $2 \%$ and soy flours, were used as controls and reference material, respectively.

\subsection{DNA quantification and purity}

The quality and the quantity of the DNA solutions were determined by UV-spectroscopy (Nanodrop 2000, Thermo Scientific). The absorbance of the DNA solutions was measured using a spectrophotometer. The purity of the extracted DNAs was determined by the ratio of the absorbance at 260 and $280 \mathrm{~nm}$.

\subsection{Conventional and Real Time PCR}

PCR amplification was carried out in a PCR mix of $25 \mu \mathrm{l}$ on a thermal cycler (Techne TC-3000). The final concentration of each PCR was as follows: $2.5 \mathrm{ml}$ of $10 \mathrm{x}$ PCR buffer (Finnzymes, Thermo); $10 \mathrm{ng}$ of genomic DNA; 0.1 to $0.5 \mu \mathrm{M}$ of each primers; $200 \mu \mathrm{M}$ of dNTPs mix; and 0.2 unit/reaction of Taq DNA polymerase (Fermentas, EP0402). Primers used are listed in Table 2 (Querci and Mazzara, 2006, Lee et al., 2004). Quantitative Real Time PCR was performed according to a previous study (Kuribara et al., 2002). An aliquot of $25 \mathrm{ml}$ of the reaction solution contained $12.5 \mu \mathrm{M}$ Taqman Universal Master Mix, $0.5 \mu \mathrm{M}$ forward and reverse primers, $0.2 \mu \mathrm{M}$ probe, and $50 \mathrm{ng}$ template DNA. All reactions of the real-time PCR were performed in triplicate using 3 wells. The copy number of each sample was calculated by interpolation with the calibration curves generated using the reference materials. The measured copy numbers were used to determine GMO amount (\%), as previously reported (Kuribara et al., 2002). The reaction conditions of PCR are shown in Table 3. $0.1,0.5 \%$, and $1 \%$ Roundup Ready ${ }^{\mathrm{TM}}$ Certified Reference Materials were used to obtain the standard curves. Four different concentrations $(1 ; 10$; $50 ; 100 \%)$ of DNA were used for the generation of the standard graphics. Real Time analysis was performed using a Stratagene Mx3005P QPCR system.

Table 1. Modifications used in CTAB DNA extraction.

\begin{tabular}{|c|c|c|c|c|c|c|c|c|}
\hline & $\begin{array}{l}\text { Original } \\
\text { protocol }\end{array}$ & Soy Flour & $\begin{array}{c}\text { Soy Chop } \\
\text { Meat }\end{array}$ & Soy Meat & Tofu & $\begin{array}{l}\text { Soy Milk } \\
\text { \&Cream }\end{array}$ & Soy Sprouts & Soy Coffee \\
\hline Starting Material (mg) & 100 & - & 200 & - & 300 & 200 & 200 & - \\
\hline $\mathrm{dH}_{2} \mathrm{O}(\mu \mathrm{l})$ & 300 & - & 600 & - & - & - & - & - \\
\hline Extra chloroform step & - & + & - & - & - & - & - & - \\
\hline CTAB $(\mu \mathrm{l})$ & 500 & - & - & - & - & - & 1000 & - \\
\hline $\begin{array}{l}\text { CTAB precipitation } \\
\text { buffer }\end{array}$ & 2 volumes & - & - & - & - & - & 4 fold volume & 4 fold volume \\
\hline $\mathrm{NaCl}(\mu \mathrm{l})$ & 350 & 500 & - & - & - & - & - & - \\
\hline Last Centrifuge & $10 \mathrm{~min}$ & $10 \mathrm{~min}$ & - & - & - & $20 \mathrm{~min}$ & $10 \mathrm{~min}$ & - \\
\hline
\end{tabular}

- Means no change from original protocol.

Table 2. Primers and probs used in PCR reactions.

\begin{tabular}{|c|c|c|c|}
\hline Target & Primer/Prob & Sequences $\left(5^{\prime}-3^{\prime}\right)$ & Product size (bp) \\
\hline \multicolumn{4}{|c|}{ Conventional PCR } \\
\hline Lectin & $\begin{array}{l}\text { GMO3 } \\
\text { GMO4 }\end{array}$ & $\begin{array}{c}\text { GCCСТCTACTCCACССССАTCC } \\
\text { GCCСАTCTGCAAGCСTTTTTGTG }\end{array}$ & 118 \\
\hline $35 \mathrm{~S}$ promotor & $\begin{array}{l}\text { P35S-cf3 } \\
\text { P35S-cr4 }\end{array}$ & $\begin{array}{c}\text { CCACGTCTTCAAAGCAAGTGG } \\
\text { TCCTCTCCAAATGAAATGAACTTCC }\end{array}$ & 123 \\
\hline NOS terminator & $\begin{array}{l}\text { tNOS } 2-5^{\prime} \\
\text { tNOS } 2-3^{\prime}\end{array}$ & $\begin{array}{l}\text { GTCTTGCGATGATTATCATATAATTTCTG } \\
\text { CGCTATATTTTGTTTTCTATCGCGT } \\
\text { Real Time PCR }\end{array}$ & 151 \\
\hline Lectin gene & $\begin{array}{l}\text { Leln02-5 } \\
\text { Leln02-3 } \\
\text { Le1-Taq }\end{array}$ & $\begin{array}{c}\text { GCCCTCTACTCCACCCCCA } \\
\text { GCCCATCTGCAAGCCTTTTT } \\
\text { FAM-AGCTTCGCCGCTTCCTTCAACTTCAC-TAMRA }\end{array}$ & 118 \\
\hline $\begin{array}{l}\text { CTP4-CP4 } \\
\text { EPSPS }\end{array}$ & $\begin{array}{l}\text { RRS } 01-5 \\
\text { RRS } 01-3 \\
\text { RRS-Taq }\end{array}$ & $\begin{array}{l}\text { CCTTTAGGATTTCAGCATCAGTGG } \\
\text { GACTTGTCGCCGGGAATG } \\
\text { FAM-CGCAACCGCCCGCAAATCC-TAMRA }\end{array}$ & 121 \\
\hline
\end{tabular}


Table 3. Reaction conditions for lectin, 35S, and NOS amplification.

\begin{tabular}{lcclc}
\hline & Lectin PCR & CaMV 35S PCR & NOS PCR & Real Time for EPSPS \\
\hline Steps & & & & \\
Initial denaturation & $95^{\circ} \mathrm{C}, 3 \mathrm{~min}$ & $95^{\circ} \mathrm{C}, 5 \mathrm{~min}$ & $95^{\circ} \mathrm{C}, 5 \mathrm{~min}$ & $95^{\circ} \mathrm{C}, 10 \mathrm{~min}$ \\
Denaturation & $95^{\circ} \mathrm{C}, 30 \mathrm{sec}$ & $95^{\circ} \mathrm{C}, 30 \mathrm{sec}$ & $95^{\circ} \mathrm{C}, 30 \mathrm{sec}$ & $65^{\circ} \mathrm{C}, 30 \mathrm{sec}$ \\
Annealing & $63^{\circ} \mathrm{C}, 30 \mathrm{sec}$ & $60^{\circ} \mathrm{C}, 30 \mathrm{sec}$ & $72^{\circ} \mathrm{C}, 30 \mathrm{sec}$ & $60{ }^{\circ} \mathrm{C}, 1 \mathrm{~min}$ \\
Extension & $72^{\circ} \mathrm{C}, 30 \mathrm{sec}$ & $72^{\circ} \mathrm{C}, 30 \mathrm{sec}$ & $72^{\circ} \mathrm{C}, 5 \mathrm{~min}$ & \\
Final extension & $72^{\circ} \mathrm{C}, 3 \mathrm{~min}$ & $72^{\circ} \mathrm{C}, 5 \mathrm{~min}$ & 35 & 45 \\
Cycles & 30 & 35 & & 35 \\
\hline
\end{tabular}

Table 4. DNA yield (ng DNA/mg sample) obtained by DNA extraction of samples, \pm values indicate standard deviations.

\begin{tabular}{lrc}
\hline \multicolumn{1}{c}{ Samples } & \multicolumn{1}{c}{ DNA yield } & \multicolumn{1}{c}{$\mathrm{A}_{260 / 280}$} \\
\hline Flour & $186 \pm 0.12 \mathrm{ng} / \mu \mathrm{l}$ & $1,85 \pm 0.008$ \\
Chop meat & $337.2 \pm 0.61 \mathrm{ng} / \mu \mathrm{l}$ & $1.97 \pm 0.009$ \\
Meat & $531.4 \pm 0.36 \mathrm{ng} / \mu \mathrm{l}$ & $1.92 \pm 0.012$ \\
Sprout-1 & $166.2 \pm 0.08 \mathrm{ng} / \mu \mathrm{l}$ & $2.03 \pm 0.004$ \\
Sprout-2 & $158.3 \pm 0.16 \mathrm{ng} / \mu \mathrm{l}$ & $1.96 \pm 0.008$ \\
Coffee & $28.1 \pm 0.14 \mathrm{ng} / \mu \mathrm{l}$ & $1.91 \pm 0.016$ \\
Cream & $31.1 \pm 0.04 \mathrm{ng} / \mu \mathrm{l}$ & $2.01 \pm 0.005$ \\
Milk & $73 \pm 0.21 \mathrm{ng} / \mu \mathrm{l}$ & $1.83 \pm 0.008$ \\
Tofu & $155.3 \pm 0.16 \mathrm{ng} / \mu \mathrm{l}$ & $1.95 \pm 0.012$ \\
\hline
\end{tabular}

\section{Results and discussion}

\subsection{Evaluation of DNA yield}

The DNA isolated by CTAB method was quantified using a spectrophotometer at the absorbance of 260 and $280 \mathrm{~nm}$. Three replicates were used to quantify the DNA content. The results in Table 4 show that the CTAB-based protocols produced optimum DNA yield. CTAB method produced a clear DNA band on the agarose gel (Figure 1). As for the processed materials, it is recommended to modify the DNA extraction protocol because the efficiency changes according to the level of processing. In the present study, it was found that it is better to start with more material then recommended in the original protocol for processed semi solid materials. On the other hand, for better DNA yield, it is recommended to increase the amount of CTAB precipitation buffer and prolong last centrifuge time.

\subsection{PCR amplifications}

Lectin gene was successfully amplified in all samples. This result showed that the isolated DNAs were amplifiable and contained soy DNA (Figure 2). After PCR amplifications of the lectin gene, all samples were subjected to PCR amplification of the $35 \mathrm{~S}$ promoter and NOS terminator. Most currently available GMOs contain three genetic elements as regulator sequences: the cauliflower mosaic virus (CaMV) $35 \mathrm{~S}$ promoter, the nopalin synthase (nos) terminator, and the kanamycin-resistance marker gene (nptII) (James, 2011).

5 out of 9 samples were positive for the P35S promoter and NOS terminator (Figure 3, Figure 4): tofu, soy chop meat, soy flour, soy cream, soy milk. The other samples were negative for both P35S promoter and NOS terminator.

\subsection{Quantification of transgene in soy samples}

5 positive samples for $35 \mathrm{~S}$ and NOS were analyzed using RR soy event-specific real-time PCR. The calculation was performed using the Stratagene Relative Quantification Software applying the following basic steps: determination of the relative ratio of Roundup and the amount of Roundup Ready ${ }^{\mathrm{TM}}$ soy specific target DNA was expressed as a relative ratio to a soy reference gene (Figure 5). The final result was expressed as a ratio of GMO (EPSPS): reference gene (lectin) in the sample (Table 5). None of the five samples contained RR soy over the $0.9 \%$ threshold limit. The results demonstrated the presence of RR soybean in processed soy derived products commercially available in Turkey.

Screening food products for the presence of GMOs has been performed by PCR because the specific DNA sequences in GM products can be detected and amplified easily and reliably. Detection of GMO in foodstuffs consists of two steps: extraction and purification of DNA and amplification of the inserted DNA by PCR. In foodstuffs, isolated DNA can vary in length due to processing, but very low concentrations could be adequate for the detection of GMO material. In theory, PCR could determine a single target molecule in DNA mixture (Holst-Jensen \& Berdal, 2004).

In the present study, an operative analysis for detection of GM food samples containing soy was performed. The qualitative PCR based on a three-step analysis technique was used to determine the GM plant content and to estimate the GM plant type. The first step involves the amplification of specific soy gene, lectin, from isolated DNA. The second step entails amplification of GM plant specific sequences, represented by the $35 \mathrm{~S}$ promoter and NOS terminator, to screen the presence of transgenic materials in the samples. All positive samples for $35 \mathrm{~S}$ and NOS were subjected to analysis of transgenic event (EPSPS) specific real-time PCR (Querci and Mazzara, 2006).

The results obtained showed that all 9 samples had lectin genes. This confirms that the tested samples contained soybean, but only tofu, soy chop meat, soy flour, soy cream, and soy milk were positive for $35 \mathrm{~S}$ and NOS regulatory elements. To determine the quantitation of GMO presence of the transgenic event, quantitative real-time PCR was performed for EPSPS using specific primers. However, it was found that $100 \%$ of the tested food samples contained EPSPS enzyme below 0.1 per cent. In Turkey, GMO containing foods are not allowed. The products used in this study were collected from local markets in 2009. Therefore, it would be essential to evaluate local markets to update and confirm the results. 


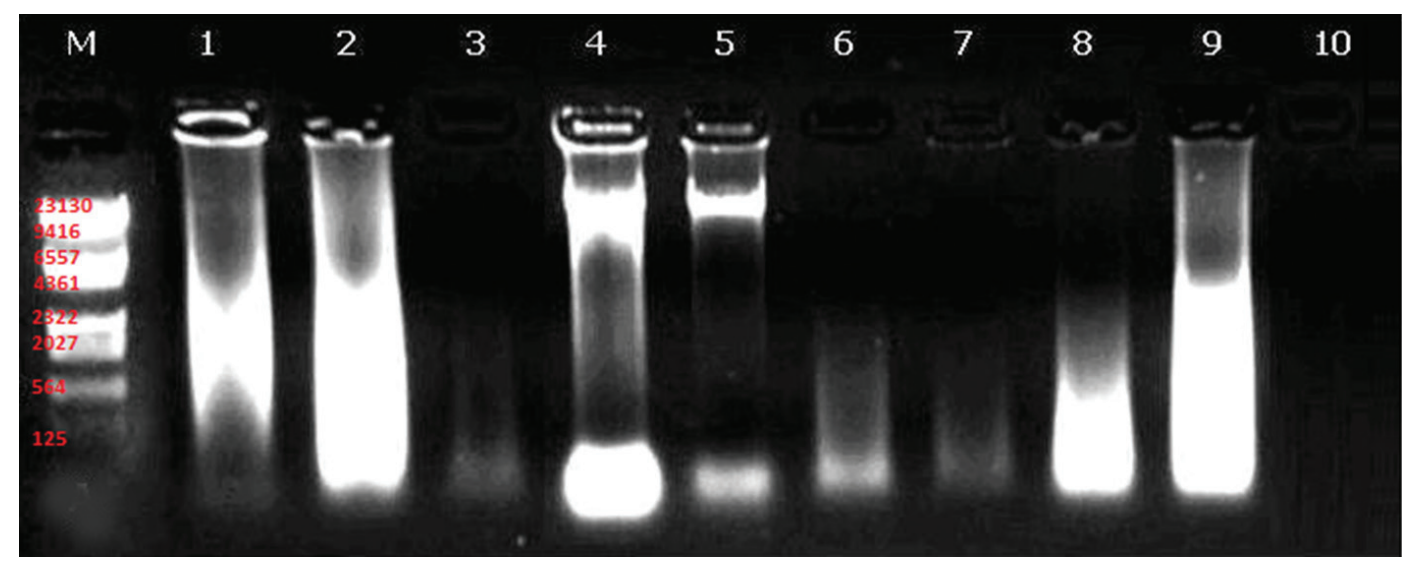

Figure 1. Agarose gel electrophoresis (1.8\%) of genomic DNA using the CTAB method with 3 replications. M: Marker, Fermentas SM0103, 1) Soy flour; 2) Soy meat; 3) Soy cream; 4) Soy sprout-1;5) Soy sprout-2;6) Soy milk; 7) Soy coffee; 8) Tofu; 9) Soy chop meat; 10) Isolation blank control.

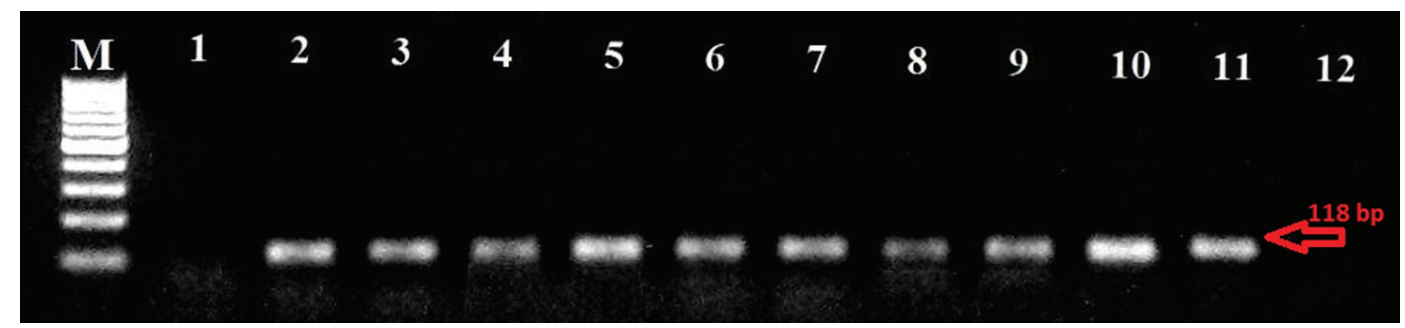

Figure 2. Agarose gel electrophoresis (1.8\%) of amplification products of lectin from samples 1) Corn DNA (negative control); 2) \% 0 SRM (positive control) 3) Soy flour; 4) Soy meat; 5) Soy cream; 6) Soy milk; 7) Soy sprout-1; 8) Soy sprout-2; 9) Soy coffee; 10) Tofu; 11) Soy chop meat; 12) no template control; M) Marker (Fermentas, GeneRuler ${ }^{\mathrm{TM}} 100$ bp DNA Ladder, 100-1000 bp).

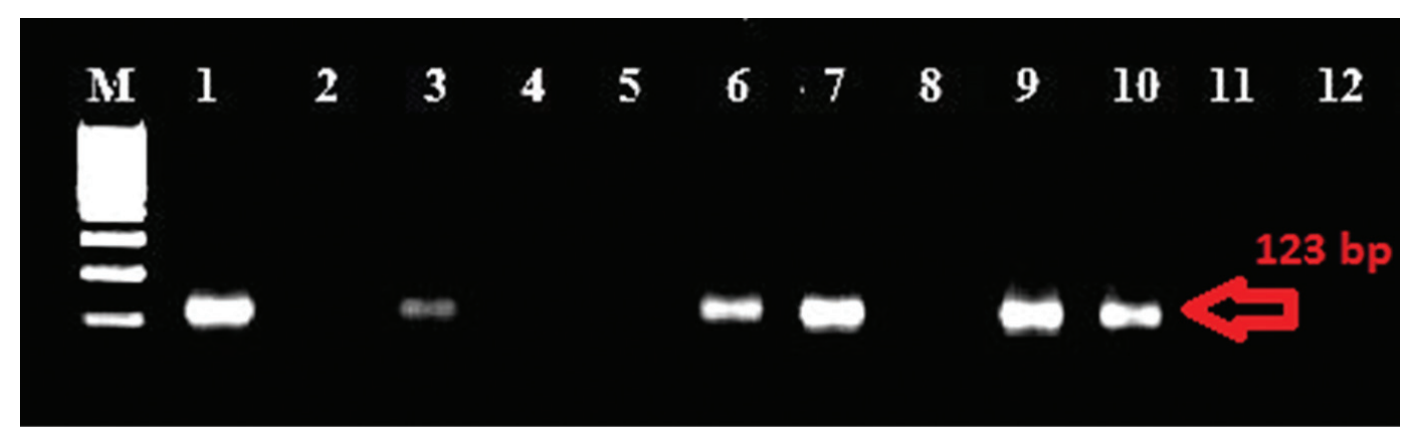

Figure 3. Agarose gel electrophoresis (1.8\%) of amplification products of 35 S promoter from samples 1 ) \% 2 SRM (positive control); 2 ) \% 0 SRM (negative control); 3) Tofu; 4) Soy sprout-1; 5) Soy sprout-2; 6) Soy chop meat; 7) Soy flour; 8) Soy meat; 9) Soy cream; 10) Soy milk; 11) Soy coffee; 12) No template control; M) Marker (Fermentas, GeneRuler ${ }^{\mathrm{TM}} 100$ bp DNA Ladder, 100-1000 bp).

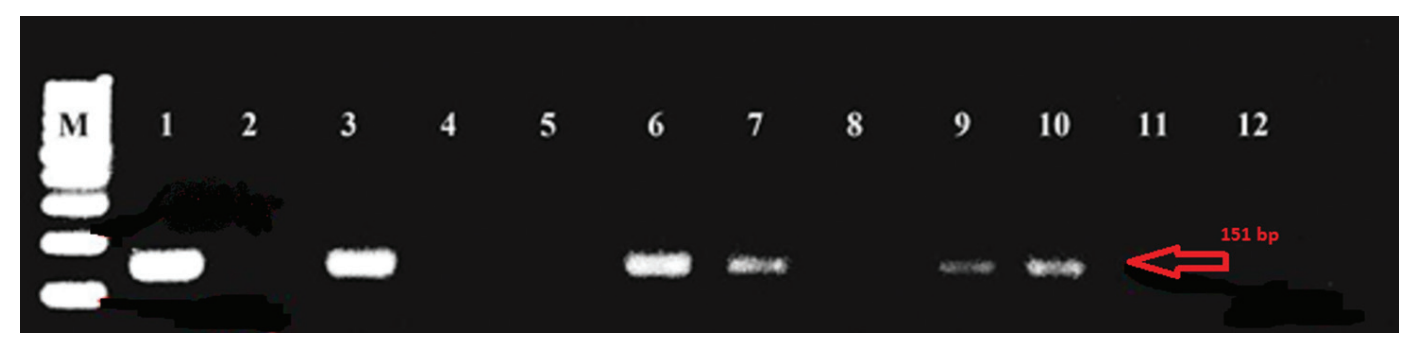

Figure 4. Agarose gel electrophoresis (1.8\%) of amplification products of NOS terminator from samples. 1) \% 2 SRM (positive control); 2 ) \% 0 SRM (negative control); 3) Tofu; 4) Soy sprout-1; 5) Soy sprout-2; 6) Soy chop meat; 7) Soy flour; 8) Soy meat; 9) Soy cream; 10) Soy milk; 11) Soy coffee; 12) No template control; M) Marker (Fermentas, GeneRuler ${ }^{\mathrm{TM}} 100$ bp DNA Ladder, 100-1000 bp). 

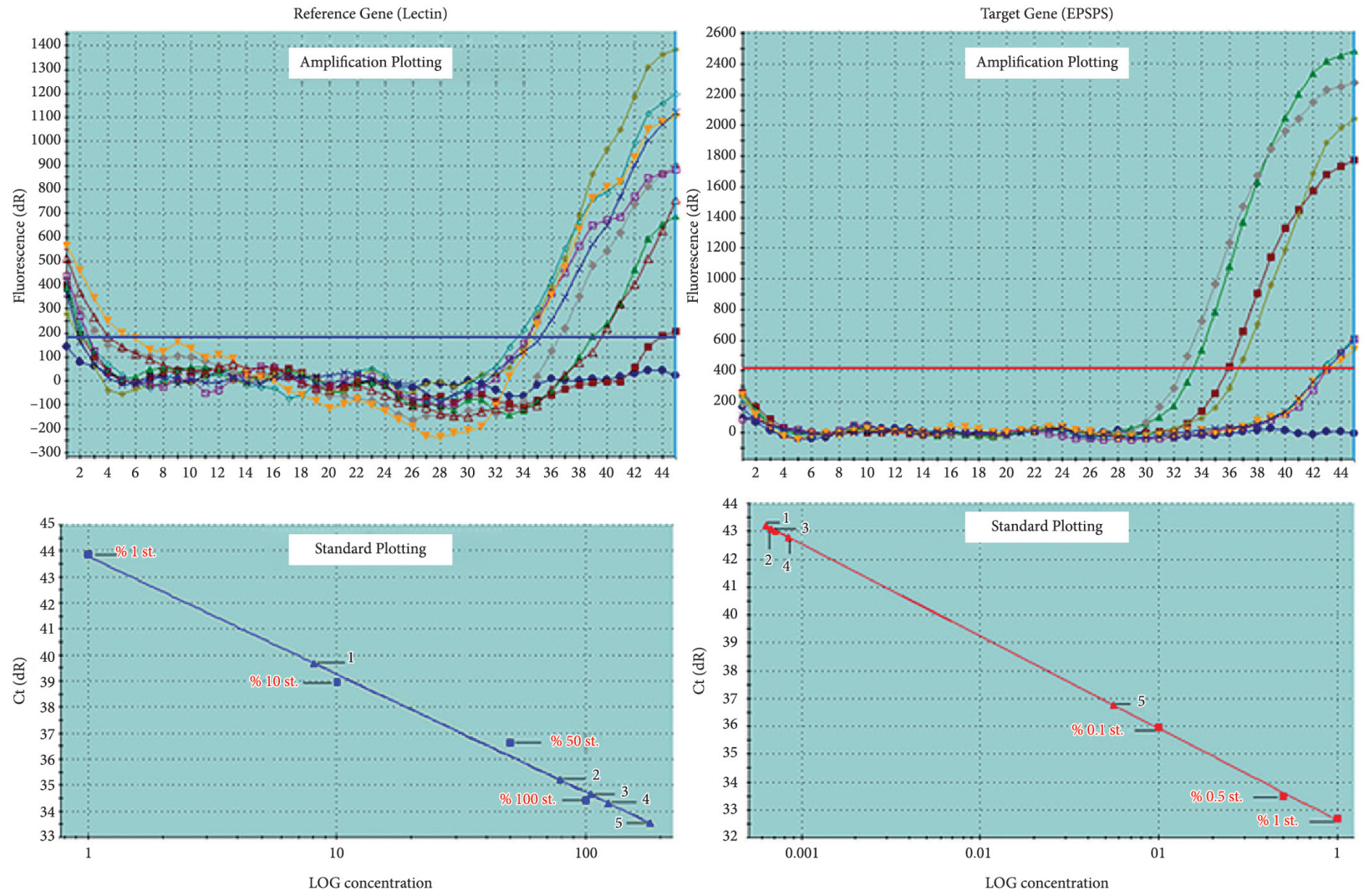

Figure 5. Real Time PCR quantification for Roundup Ready ${ }^{\mathrm{TM}}$ Soybean products. Rsq values of standard curves are: $0.99\left(\mathrm{y}=-4.527^{\star} \log (\mathrm{x})+43.78\right)$, for Lectin, and $0.997\left(\mathrm{y}=-3.308^{\star} \log (\mathrm{x})+32.61\right)$, for EPSPS.

Table 5. CTP4-CP4 EPSPS Real Time PCR quantification of samples.

\begin{tabular}{ccccc}
\hline Sample no. & Sample Type & Sample type & Ct & Relative amount (\%) \\
\hline 1 & No template control & NTC & - & - \\
2 & $\% 0.1$ st. & Standard & 35.95 & 0.1 \\
3 & $\% 0.5$ st. & Standard & 33.49 & 0.5 \\
4 & \% st. & Standard & 32.68 & 1 \\
5 & Soy Tofu & Unknown & 36.75 & 0.05 \\
6 & Soy Flour & Unknown & 42.78 & 0.00084 \\
7 & Soy Chop Meat & Unknown & 43.10 & 0.00067 \\
8 & Soy Milk & Unknown & 43.19 & 0.00063 \\
9 & Soy Cream & Unknown & 43.02 & 0.0007 \\
\hline
\end{tabular}

\section{Conclusion}

The food samples were collected from Turkish markets in 2009. At that time, Turkish Biosafety Law had not yet come into force, but now, due to the evaluation of the risk assessment of EPSPS soy by the Turkish Biosafety Committee, this soybean event is allowed to be used only in feed and related products with particular requirements established by law (Turkey, 2011).

\section{Acknowledgements}

This study was supported by the Research Fund of Istanbul University. Project no: 10728.

\section{References}

Block, M. D., Botterman, J., Vandewiele, M., Dockx, J., Thoen, C., Gosselé, V., Movva, N. R., Thompson, C., Montagu, M. V., \& Leemans, J. (1987). Engineering herbicide resistance in plants by expression of a detoxifying enzyme. The EMBO Journal, 6(9), 25132518. PMid:16453789.

Branquinho, M. R., Ferreira, R. T. B., Cardarelli-leite, P. (2012). Use of real-time PCR to evaluate two DNA extraction methods from food. Ciência e Tecnologia de Alimentos, 32(1), 112-118.

Fraiture, M.-A., Herman, P., Taverniers, I., De Loose, M., Deforce, D., \& Roosens, N. H. (2014). An innovative and integrated approach based on DNA walking to identify unauthorised GMOs. Food Chemistry, 
147, 60-69. http://dx.doi.org/10.1016/j.foodchem.2013.09.112. PMid:24206686

Friedman, M., \& Brandon, D. L. (2001). Nutritional and health benefits of soy proteins. Journal of Agricultural and Food Chemistry, 49(3), 1069-1086. http://dx.doi.org/10.1021/jf0009246. PMid:11312815

Holst-Jensen, A., \& Berdal, K. G. (2004). The modular analytical procedure and validation approach and the units of measurement for genetically modified materials in foods and feeds. Journal of AOAC International, 87(4), 927-936. PMid:15295887.

James, C. (2011). Global status of commercialized biotech/GM Crops (ISAAA Brief, Vol. 43). Ithaca: ISAAA.

Korth, K. L. (2008). Genes and traits of interest for transgenic plants. In C. N. Stewart (Ed.), Plant biotechnology and genetics: principles, techniques and applications (pp. 193-215). New York: John Wiley and Sons. http://dx.doi.org/10.1002/9780470282014.ch8.

Kuribara, H., Shindo, Y., Matsuoka, T., Takubo, K., Futo, S., Aoki, N., Hirao, T., Akiyama, H., Goda, Y., Toyoda, M., \& Hino, A. (2002). Novel reference molecules for quantitation of genetically modified maize and soybean. Journal of AOAC International, 85(5), 1077 1089. PMid:12374407.

Lee, S., Kim, J., Han, J. J., Han, M. J., \& An, G. (2004). Functional analyses of the flowering time gene OsMADS50, the putative SUPPRESSOR OF OVEREXPRESSION OF CO 1/AGAMOUSLIKE 20 (SOC1/AGL20) ortholog in rice. The Plant Journal, 38(5), 754-764. http://dx.doi.org/10.1111/j.1365-313X.2004.02082.x. PMid:15144377

Moellenbeck, D. J., Peters, M. L., Bing, J. W., Rouse, J. R., Higgins, L. S., Sims, L., Nevshemal, T., Marshall, L., Ellis, R. T., Bystrak, P. G., Lang, B. A., Stewart, J. L., Kouba, K., Sondag, V., Gustafson, V., Nour, K., Xu, D., Swenson, J., Zhang, J., Czapla, T., Schwab, G., Jayne, S., Stockhoff, B. A., Narva, K., Schnepf, H. E., Stelman, S. J., Poutre, C., Koziel, M., \& Duck, N. (2001). Insecticidal proteins from Bacillus thuringiensis protect corn from corn rootworms. Nature
Biotechnology, 19(7), 668-672. http://dx.doi.org/10.1038/90282. PMid:11433280

Monsanto Company. (2000). Updated molecular characterization and safety assessment of RoundUp ReadyTM soybean event 40-3-2. Product Safety Centre. Monsanto Report.

Mullis, K. B., \& Faloona, F. A. (1987). Specific synthesis of DNA in vitro via a polymerase-catalyzed chain reaction. Methods in Enzymology, 155, 335-350. http://dx.doi.org/10.1016/0076-6879(87)55023-6. PMid:3431465

Querci, M., \& Mazzara, M. (2006). Characteristics of RoundUp ReadyTM Soybean, MON810 maize and Bt-176 maize. In M. Querci, M. Jermini \& G. V. Eede Den (Eds.), The analysis of food samples for the presence of genetically modified organisms (pp. 1116). Luxemburg: European Commission Joint Research Centre.

Randhawa, G. J., Morisset, D., Singh, M., \& Žel, J. (2014). GMO matrix: a cost-effective approach for screening unauthorized genetically modified events in India. Food Control, 38, 124-129. http://dx.doi. org/10.1016/j.foodcont.2013.10.013.

Rott, M. E., Lawrence, T. S., Wall, E. M., \& Green, M. J. (2004). Detection and quantification of roundup ready soy in foods by conventional and real-time polymerase chain reaction. Journal of Agricultural and Food Chemistry, 52(16), 5223-5232. http://dx.doi.org/10.1021/ jf030803g. PMid:15291500

Somma, M. (2006). Extraction and purification of DNA. In M. Querci (Ed.), Training course on: the analysis of food samples for the presence of genetically modified organisms user manual. Session 4. Luxemburg: European Communities.

Song, Q., Wei, G., \& Zhou, G. (2014). Analysis of genetically modified organisms by pyrosequencing on a portable photodiode-based bioluminescence sequencer. Food Chemistry, 154, 78-83. http:// dx.doi.org/10.1016/j.foodchem.2014.01.001. PMid:24518318

Turkey. (2011). Biosecurity Committee Decisions, decision no.1, 2 and 3. Official Gazette of The Republic of Turkey. No. 27827. 